\title{
axe- \\ Sooty Blotch and Flyspeck of Apple: Etiology, Biology, and Control
}

\section{Sharon M. Williamson and Turner B. Sutton North Carolina State University, Raleigh}

Sooty blotch and flyspeck are two of the most common diseases of pome fruits in many moist, temperate growing regions of the world. In the United States, the diseases are most severe on apples in the Southeast, but they occur throughout the apple growing regions in the East and Midwest. Although the diseases do not result in a yield loss, they cause considerable economic loss to growers of fresh market fruit because of reduced fruit quality (Fig. 1) $(63,89)$.

Fungi associated with these diseases were not described in the literature until the 1830s. However, it is probable that sooty blotch and flyspeck have commonly occurred on apples in the United States since the introduction of the fruit from Europe in the 1600s (5). Some of the first illustrations of the two diseases can be seen in a series of unpublished watercolors painted by Elizabeth Coxe McMurtrie and her sisters from 1810 to 1828 (see cover illustration). Perhaps the first description of sooty blotch in the literature was by Sprague (83) in 1856, who described the disease on apple fruit as "a dark, clouded stain, generally round, from a half to quarter of an inch in diameter" exhibiting "a radiating network of branched filaments." However, further in his description, he stated that the "mycelium disappears leaving them [thyriothecia: our word] strongly defined as black spots," which is more characteristic of flyspeck and is indicative of some of the early confusion surrounding the etiology of the two diseases. Sooty

Dr. Sutton's address is: North Carolina State University, Raleigh 27695-7616

E-mail: turner_sutton@ncsu.edu

Publication no. D-2000-0424-01F

(C) 2000 The American Phytopathological Society blotch was referred to by various names in the early literature, including fruit spot, ink spot, sooty fungus, sooty spot, and cloud (11).

Sooty blotch and flyspeck did not receive as much attention in the early horticultural literature as more destructive diseases such as scab, fire blight, and bitter rot. Little reference was made to sooty blotch and flyspeck until the late 1800s and early 1900 s, when fruit quality became more important. However, the diseases were widespread, as noted by C. J. Sprague (83), who exhibited specimens of Spilocea pomi Schw. (teleomorph Venturia inaequalis, cause of apple scab) and Asteroma pomigena Schw. (which he believed to be the name of the fungus that caused sooty blotch) at the Boston Society of Natural History in 1856. Sprague commented that "these two funguses grow very frequently upon the same fruit, and are so common that it would require a careful selection to obtain any number of individuals entirely free from their attacks."

The objectives of this article are to summarize information on the etiology of sooty blotch and flyspeck, to discuss the ecology and epidemiology of the pathogens, and to recount the evolution of control strategies for managing the diseases.

\section{Sooty Blotch}

Etiology. In 1832, Schweinitz (73) described a fungus on Newtown Pippin apples collected in Pennsylvania, which he named Dothidea pomigena Schw. The description, although brief, was sufficient to associate the fungus with apple sooty blotch. In 1856, Sprague (84) listed Asteroma pomi Schw. on apple among a number of fungi collected near Boston. It is not clear why Sprague chose to use the name $A$. pomi instead of $D$. pomigena, except that Schweinitz included $D$. pomigena under the Section Asteroma. The name was subsequently changed to Phyllachora pomigena (Schw.) Sacc. by Saccardo in 1883 (71). $P$. pomigena was used in the literature until the early 1900 s as the scientific name of the fungus that causes sooty blotch.

In 1900, Selby (74), in the Ohio Experiment Station Bulletin entitled "Condensed Handbook of the Diseases of Cultivated Plants in Ohio," placed sooty

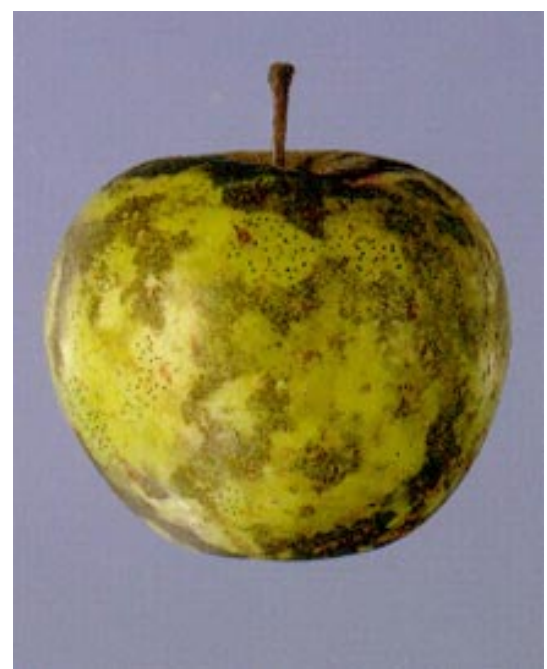

Fig. 1. Apple covered with colonies of sooty blotch and flyspeck fungi. 
blotch and flyspeck under the same name, Leptothyrium pomi (Mont. \& Fr.) Sacc., which was considered the cause of flyspeck. (In a subsequent edition of his bulletin in 1910 [75], he listed sooty blotch and flyspeck separately with different causal agents.) However, the most definitive publication in the early 1900 s was that of Duggar's "Fungous Diseases of Plants" (19), in which he stated that sooty blotch and flyspeck were apparently stages of the same fungus and were caused by L pomi. Duggar based his conclusion on unpublished data provided by B. F. Floyd of the Florida Experiment Station. Subsequently, Hesler and Whetzel (31), in the first text on tree fruit diseases published in the United States, listed L. pomi as the cause of both diseases. Thus, in the early 1900s, both $L$. pomi and $P$. pomigena were used in the literature to refer to sooty blotch until Colby (11) did an extensive study of the disease and concluded that sooty blotch and flyspeck were caused by different fungi. Colby established a new genus, Gloeodes, to accommodate the apple sooty blotch fungus, which he named Gloeodes pomigena (Schw.) Colby. He described $G$. pomigena as having circular pycnothyria 70 to $100 \mu \mathrm{m}$ in diameter. Conidia were oblong, straight or slightly curved, almost hyaline, one-celled, 10 to $20 \times 4$ to $7 \mu \mathrm{m}$, and appeared to be sessile or borne on short conidiophores. Conidia were released through cracks in the shield of the pycnothyrium.

Colby (11) observed considerable variation in the growth of G. pomigena on apple fruit and described three mycelial (thallus) types: fern-like, honeycomb, and reticulate. Groves (25) redescribed and renamed the mycelial types: ramose (fern-like, sensu Colby), punctate, fuliginous (reticulate and honeycomb types, sensu Colby), and rimate. Although Groves (25) and subsequent researchers $(32,86,87)$ observed considerable variation in the symptoms of sooty blotch, G. pomigena was accepted as the sole cause of sooty blotch until 1998, when Johnson et al. (39) showed that sooty blotch in the United States is a disease complex caused by at least three different fungi. Peltaster fructicola Johnson, Sutton \& Hodges $(38,39)$ was described as a new species and associated with ramose colonies. However, recent studies have shown that it should have been associated with punctate colonies instead of ramose colonies (S. M. Williamson and T. B. Sutton, unpublished data). Leptodontium elatius (Mangenot) de Hoog (14) was associated with fuliginous colonies (39), and Geastrumia polystigmatis Batista \& M.L. Farr (60) was associated with ramose colonies $(36,39)$. Johnson et al. (39) were unable to find a fungus matching the description of G. pomigena in a large collection of fruit from North Carolina and seven other states in the eastern United States. Kern (Simone Kern, personal communication) has recently associated four fungi, including $P$. fructicola, with the disease in Germany. It is likely that other fungi will be associated with sooty blotch as the disease is more widely studied throughout the world.

Signs. Colonies vary in color, shape, and size according to which fungus is growing on the apple cuticle. They consist of a mycelial network and conidiophores, pycnothyria, or thyriothecia. The number, size, and arrangement of fruiting bodies, as well as the type of mycelial growth, differ among the fungi. Colonies vary from olive green to black and may be small and circular or large and diffuse. Some colonies cover a large portion of the fruit as a result of secondary spread from conidia, whereas other colonies remain discrete and do not spread $(25,39)$.

Causal organisms. Thalli of L. elatius consist of a reticulate network of mycelium, have diffuse margins, and are ir- regular in shape. Fuliginous colonies range from small and dark to large and diffuse (Fig. 2A and B). Conidiophores, two to three cells long and unbranched, arise from the thallus, and three to five conidia are produced sympodially on the terminus of the conidiophore. Conidia are hyaline, smooth, thin-walled, one-celled, cylindrical, often curved with inconspicuous basal scars, and 3.8 to $4.8 \times 1.6 \mu \mathrm{m}$ (Fig. $2 \mathrm{C}$ ) (39).

Thalli of $P$. fructicola consist of a reticulate network of mycelium and numerous pycnothyria. Punctate colonies may be small and circular or large and irregular in shape (Fig. 3A and B). Colonies are often observed "dripping" down the side of the apple fruit as a result of secondary spread by waterborne conidia (Fig. 3A). Circular pycnothyria are 81 to $113 \mu \mathrm{m}$ in diameter and contain conidia that are obovate, onecelled, hyaline, and 3.6 to $7.2 \times 0.7$ to 1.1 $\mu \mathrm{m}$ (Fig. $3 \mathrm{C}$ to E). Conidia are borne on a hyaline cell layer lining the inner surface of the shield of the pycnothyrium and are released through cracks in the shield (Fig. 3C and D) (38,39; S. M. Williamson and T. B. Sutton, unpublished data).

Thalli of $G$. polystigmatis consist of a reticulate network of mycelium and many pycnothyria (Fig. 4A). Ramose colonies are initially diffuse but become darker and denser as the colony develops. Subglobose pycnothyria, 50 to $100 \mu \mathrm{m}$ in diameter, contain conidia consisting of 6 to 14 fusiform arms, which are usually 5 to 9 septate but sometimes more, and approximately 50 $\times 3.5 \mu \mathrm{m}$ (Fig. 4B to D). Conidia are borne on conidiophores on the base of the pycnothyrium and are released through cracks in the shield (Fig. 4B) $(36,39,60)$.

P. fructicola, L. elatius, and G. polystigmatis grow superficially and do not penetrate the apple cuticle $(38,39)$. Belding (6) reported evidence that indicates $P$. fructicola and L. elatius utilize nutrients
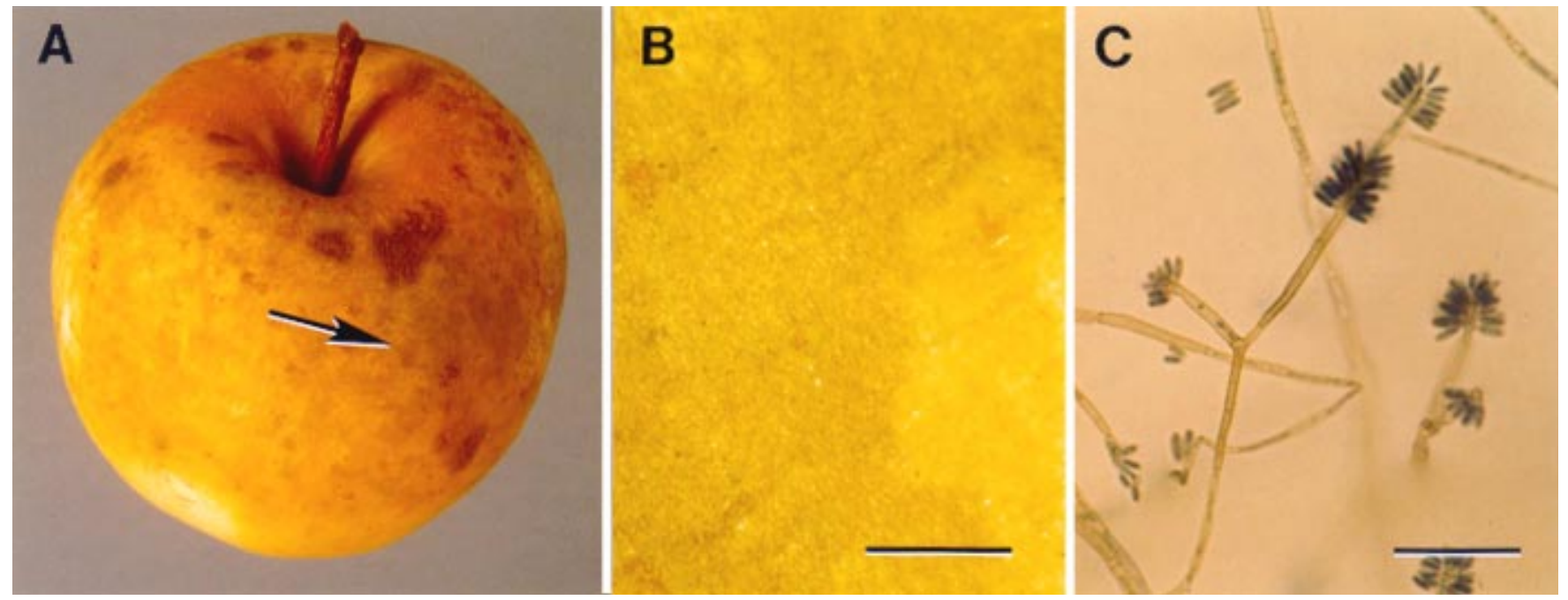

Fig. 2. (A) Leptodontium elatius, associated with fuliginous colonies (see arrow), on apple. (B) Light area on cuticle is not colonized by $L$. elatius. Bar $=0.5 \mathrm{~mm}$. (C) Conidiophores and conidia of $L$. elatius grown on water agar. Bar $=20 \mu \mathrm{m}$. Sporulation in culture is similar to that on apple fruit. However, in culture more conidia are produced on the termini of conidiophores. 
leached or exuded from the apple and that epicuticular wax does not contribute significantly to the nutrition of these fungi. Growth of both fungi was sparse on coverslips and petri dishes overlaid with epicuticular wax components of the apple cuticle. However, both fungi grew vigorously on wax placed on top of agar medium. Growth was more vigorous on wax alone when conidia were pregerminated in $0.5 \%$ apple juice and the apple juice was not removed by rinsing. Belding discounted the importance of external deposits of substrates as a source of nutrition for these fungi because they do not grow preferentially where these substrates might adhere, such as the top or bottom of fruit. In addition, these fungi do not grow on russeted cuticle, which consists of the same wax families as normal epicuticular waxes but is impermeable to water and nutrients.

Venkatasubbaiah et al. (92) found that isolates of $P$. fructicola produced trichothecolone, trichothecolone acetate, 6methylsalicylic acid, and dihydroxybenzoic acid in liquid culture, whereas an isolate of $L$. elatius did not produce these toxins. Trichothecolone acetate and 6-methylsalicylic acid inhibited growth of Colletotrichum acutatum, C. gloeosporioides,
Botryosphaeria dothidea, B. obtusa, and $P$. fructicola in vitro. Treatment of apple fruit with 6-methylsalicylic acid reduced infection by $C$. acutatum. The authors hypothesized that the ability of $P$. fructicola to produce these toxins may enable it to compete with Botryosphaeria spp. and Colletotrichum spp. on the apple cuticle. The role of these toxins in the establishment and growth of $P$. fructicola on the apple cuticle and their presence on P. fructicolainfected fruit have not been demonstrated.

Hosts. Fungi associated with sooty blotch grow on a wide range of plants, including trees, shrubs, and vines, that are near or bordering orchards $(3,11,23,32,39,95)$. Baines and Gardner (3) isolated G. pomigena from apple and crabapple fruit, and twigs of 23 other hosts. Apples developed sooty blotch when inoculated with isolates obtained from 15 hosts. Infection did not develop with isolates from blackberry. Hickey (32) isolated $G$. pomigena from twigs of apple, blackberry, willow, sycamore, sassafras, wild grape, bristly greenbrier, wild crabapple, and smooth sumac. Apples developed sooty blotch when inoculated with isolates from these hosts. Although these researchers believed that they were working with $G$. pomigena, the identity of the organism(s) they isolated is uncertain since the role of $G$. pomigena in the sooty blotch complex is not clear (39). Johnson et al. (39) observed $P$. fructicola and L. elatius on blackberry stems.

Disease development and epidemiology. Details of the life cycle of $P$. fructicola, L. elatius, and G. polystigmatis are not known; however, these fungi apparently overwinter on reservoir hosts and apple twigs and fruit. Conidia are spread by wind and rain to developing fruit and new tissues of reservoir hosts in the spring and early summer. Baines and Gardner (3) observed pycnothyria of $G$. pomigena with mature spores on twigs of 10 host species in late May and early June, and spores were disseminated in early June. Johnson et al. (39) found mature pycnothyria of $P$. fructicola on overwintered apple fruit and blackberry stems from March through May, and on apple fruit and blackberry stems throughout the growing season. Secondary infections arise from conidia produced through the summer on apple fruit or from conidia produced in new colonies on reservoir hosts that are disseminated by wind and wind-blown rain to apple fruit.

First fruit infections occurred from late April to mid-May in the southeastern
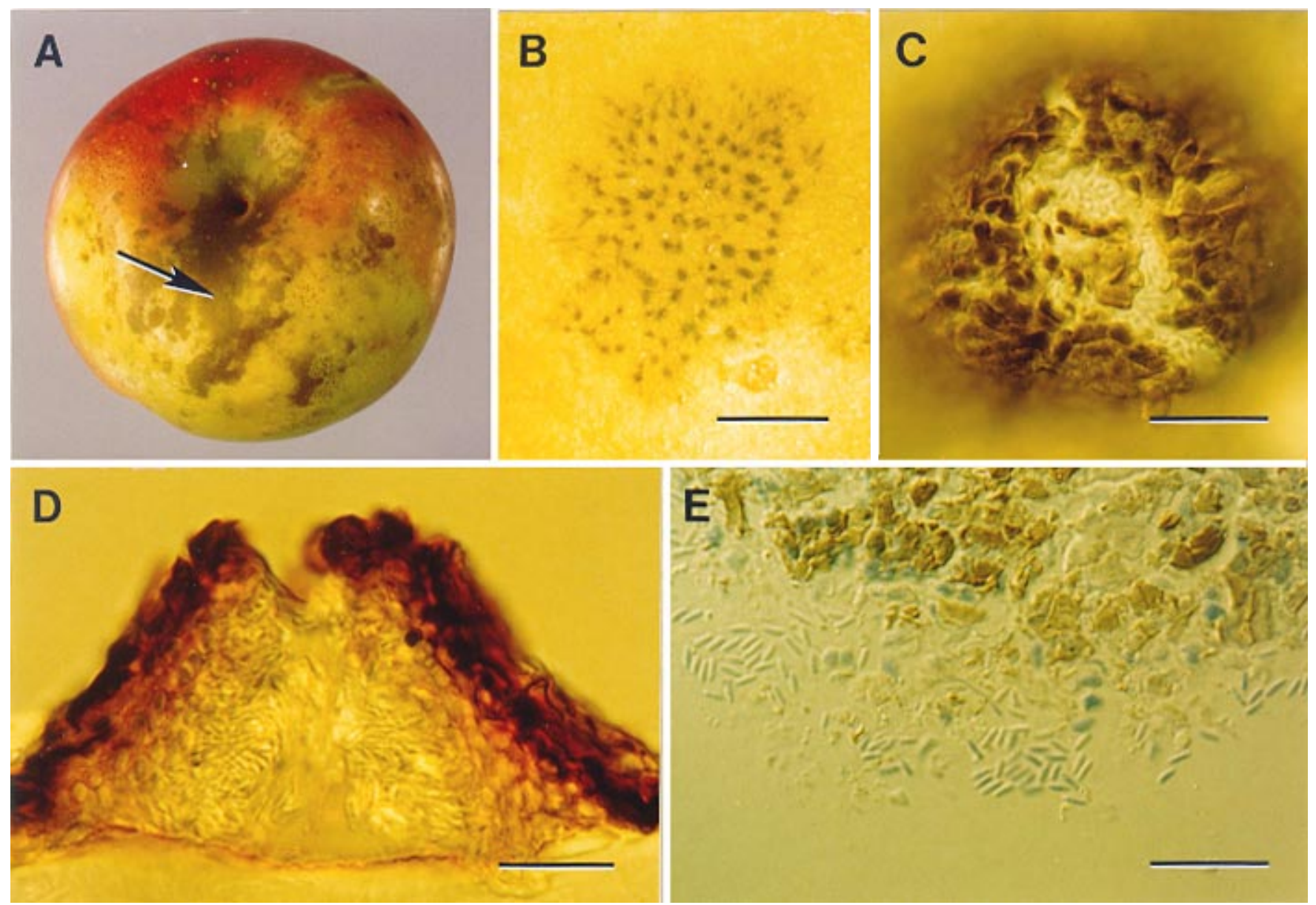

Fig. 3. (A, B) Peltaster fructicola, associated with punctate colonies, on apple. See arrow in (A). Bar = $1 \mathrm{~mm}$ in (B). (C) Pycnothyrium of $P$. fructicola that has cracked open exposing the conidia inside. Bar $=25 \mu \mathrm{m}$. (D) Section through a pycnothyrium showing conidia borne on an inverted hymenium that lines the inside of the top of the pycnothyrium. Bar $=15 \mu \mathrm{m}$. (E) Conidia released from a crushed pycnothyrium from apple. Bar $=25 \mu \mathrm{m}$. 
United States $(9,45)$ and in June in the more northern apple growing regions in the eastern United States (34). Once apples are infected in the field, it takes about 20 to 25 days for symptoms to develop; however, symptoms may become visible in 8 to 12 days under optimal conditions (89). First symptoms of sooty blotch on apple have been observed in mid-June in Alabama (45), and from early June to late July in North Carolina $(9,10)$.

Ecology. Temperature, rainfall, and relative humidity affect the development of sooty blotch $(3,9-11,41,76,87,95)$. The appearance of symptoms in North Carolina depended on the frequency and amount of rainfall in June (9). The amount of sooty blotch in Pennsylvania orchards was proportional to the amount of rainfall occurring in July, and to a lesser extent, in August and September (41). Sharp and Yoder (76) found a positive correlation between accumulated hours of relative humidity $\geq 95 \%$ and sooty blotch incidence in Virginia orchards, and that 50 to $100 \mathrm{~h}$ of high humidity accumulated before sooty blotch symptoms appeared.

Sutton and Sutton (87) found that sooty blotch severity in North Carolina was highest in orchards in the western mountains where there were cooler temperatures and long periods of dew, and in the eastern Coastal Plain where humidity was high. The authors were the first to show that the incidence and severity of punctate, ramose, fuliginous, and rimate mycelial types varied according to environmental conditions. All four mycelial types were present at each location. Severity of the punctate type decreased with increasing temperature, and incidence and severity increased with increasing hours of high relative humidity. The punctate type was the most prevalent overall and most abundant and severe in orchards in the mountains and Coastal Plain. Incidence and severity of the ramose type increased with increasing temperature and increasing amount of rainfall, but the effect of relative humidity was variable. The incidence and severity of the ramose type was greatest in orchards in the Coastal Plain. There were no significant correlations between environmental factors and incidence and severity of the fuliginous type. The fuliginous type was not clearly associated with a particular region in North Carolina. Incidence and severity of the rimate type were weakly negatively correlated to temperature and weakly positively correlated to measures of relative humidity. The rimate type was observed the least.

The effects of temperature and relative humidity on sooty blotch fungi in vitro have also been studied $(3,25,32,37)$. Johnson and Sutton (37) reported that $P$. fructicola and L. elatius respond differently to relative humidity and temperature in vitro. Optimum temperatures for mycelial growth of $P$. fructicola and $L$. elatius were 12 to $24^{\circ} \mathrm{C}$ and 16 to $28^{\circ} \mathrm{C}$, respectively. Mycelia of L. elatius, but not of P. fructicola, survived extended exposure to tem-
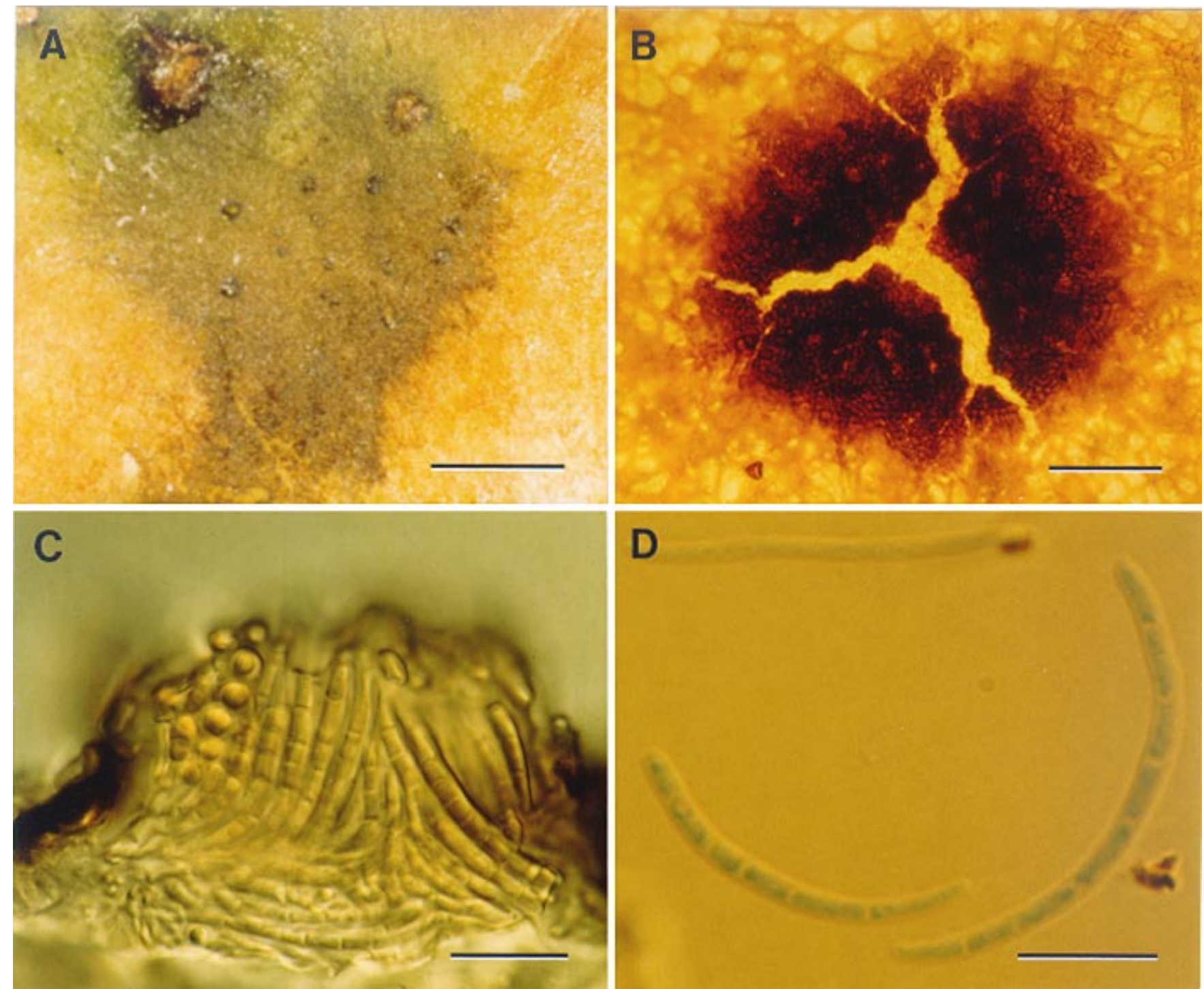

Fig. 4. (A) Geastrumia polystigmatis, associated with ramose colonies, on apple. Bar = $1 \mathrm{~mm}$. (B) Pycnothyrium of G. polystigmatis that has cracked open exposing the conidia inside. Bar $=50 \mu \mathrm{m}$. (C) Section through a pycnothyrium showing conidia inside. Bar $=$ $15 \mu \mathrm{m}$. (D) Fusiform arms of conidia that were disconnected when released from a crushed pycnothyrium from apple. Bar $=10 \mu \mathrm{m}$. 
peratures $\geq 32^{\circ} \mathrm{C}$. Neither fungus grew at $88 \%$ relative humidity, and mycelial growth was inhibited at relative humidity $<95 \%$. Conidia of $P$. fructicola germinated from 12 to $24^{\circ} \mathrm{C}$ at relative humidities $\geq 95 \%$, whereas conidia of L. elatius germinated from 12 to $32^{\circ} \mathrm{C}$ at relative humidities $\geq 97 \%$. Germination of conidia of $P$. fructicola was greatest at $24^{\circ} \mathrm{C}$ and 97 or $99 \%$ relative humidity compared with $32^{\circ} \mathrm{C}$ and $99 \%$ relative humidity for $L$. elatius. Sporulation of both fungi in Parafilm culture was greatest at 97 to $99 \%$ relative humidity. Viability of conidia of $P$. fructicola and $L$. elatius was significantly reduced after 8 and $24 \mathrm{~h}$ of air drying, respectively.

\section{Flyspeck}

Etiology. Montagne (52), in 1834, described a fungus that he named Labrella pomi Mont. mss. (Fr. in litt.) on pears and placed it in the Fungi Imperfecti. (Colby [11] examined their specimen and concluded that the fungus they named was associated with symptoms of flyspeck.) In 1880, Saccardo (70) transferred Labrella pomi to Leptothyrium? pomi (Mont. \& Fr.) Sacc., and in 1884 he removed the ? from the name (72). When Saccardo selected Leptothyrium as the genus for this fungus, he probably believed that the immature thyriothecia were pycnothyria. It has not been demonstrated that Leptothyrium is part of the life cycle of the flyspeck fungus (22). Consequently, in spite of the wide use of the name for many years, it should no longer be used $(4,22)$.

In 1930, Baines (2) agreed with Colby's conclusion that sooty blotch and flyspeck were caused by different fungi (11). Baines showed conclusively that the fruiting bodies associated with flyspeck were thyriothecia and identified the fungus as Microthyriella rubi Petrak. Von Arx (93) transferred the fungus to Schizothyrium as S. pomi (Mont. \& Fr.) v. Arx, a genus established by Desmazières (15) in 1849 for a new fungus on maple ( $S$. acerinum Desm.). Von Arx considered the fungus on maple identical to the flyspeck fungus but based his new combination on the name Labrella pomi Mont. An imperfect fungus, Zygophiala jamaicensis Mason, first described in 1945 (50) on banana, was shown in 1953 by Durbin et al. (22) to be the anamorph of $S$. pomi (then called $M$. rubi).

Signs. Colonies of flyspeck on apple fruit are round to irregular in shape and about 1 to $3 \mathrm{~cm}$ in diameter, although they may be much larger. Colonies consist of several to 50 or more shiny, black thyriothecia which are superficial on the cuticle (Fig. 5A to C) (4,89). Mycelium of the fungus is visible only with the aid of a microscope (4).

Causal organism. Thyriothecia of $S$. pomi are 150 to $375 \mu \mathrm{m}$ in diameter and 30 to $50 \mu \mathrm{m}$ high, with irregular margins. Mature thyriothecia crack irregularly in the center, exposing the asci inside (Fig. 5C and D). Asci are spherical to oval, bitunicate, 19 to $44 \times 6$ to $10.5 \mu \mathrm{m}$, and embedded singly in centrum tissue. Each ascus contains eight hyaline, two-celled ascospores 10 to $14 \times 3$ to $5 \mu \mathrm{m}$, with the upper cell shorter, wider, and less pointed than the lower cell (Fig. 5D and E) (4). When the ascus is mature, the thin outer wall of the ascus splits, and the thick inner wall absorbs water and expands upward, ejecting the ascospores into the air (40). After ascospores have discharged, thyriothecia appear as small brown rings (4).

Conidia of $Z$. jamaicensis are borne on conidiophores that consist of four parts: a modified mycelial basal cell that is subhyaline, 16 to $20 \times 4 \mu \mathrm{m}$; a conspicuous, tortuous, smooth, thick-walled, dark brown sector, 16 to $18 \times 4$ to $5 \mu \mathrm{m}$; an angular, subhyaline terminal cell, 4 to $6 \times 3$ to $4 \mu \mathrm{m}$; and two hyaline conidiogenous cells, 6 to $15 \times 4$ to $6 \mu \mathrm{m}$, borne on the terminal cell, which have few to numerous dark conidial scars. Conidia are two-celled, elliptical to obovate, smooth, hyaline, thinwalled, 13 to $20 \times 4$ to $6 \mu \mathrm{m}$, and are often shed in pairs (Fig. 5F) (4). Conidia are forcibly discharged when conidiophores are transferred from moist to dry conditions (51). As the conidiophore dries out, the stipe, or dark section of the conidiophore, contracts then suddenly elongates, discharging the conidia. Formation of a gas bubble in the stipe apparently relieves the tension, causing the conidiophore to spring back. Conidia are airborne or splash-dispersed by rainfall (4).

$Z$. jamaicensis grows on the waxy cuticle of plants. Using scanning electron microscopy, Nasu and Kunoh $(55,57)$ and Belding (6) showed that hyphae of the fungus grow on the waxy bloom of apple and other fruit and degrade the wax crystals around them. Z. jamaicensis does not penetrate the cuticle of grape berries, indicating that the fungus uses the wax alone for nutrition $(54,55)$.

Cultures of $Z$. jamaicensis isolated from various hosts in a limited area appeared very similar to Baines (2), whereas Baker et al. (4) and Nasu et al. (53) observed some variation among isolates. Lerner (46) found that the growth rate and morphology of isolates from apple fruit and blackberry canes from different geographic regions varied. The variability observed was not a result of growth medium or region of origin.

Hosts. Z. jamaicensis grows on a wide range of plants, including trees, shrubs, and vines, which are near or bordering orchards $(2,4,20,22,53,56,57,89,90)$. Baker et al. (4) listed 78 species in 36 families, and 119 species in 44 families have been reported as hosts in Japan (56). Sutton et al. (90) observed $S$. pomi on 38 species of plants around apple orchards in North Carolina; Rubus spp. were the most common host.

Isolates of the fungus collected from various hosts are able to infect apple and other hosts. Baines (2) observed flyspeck symptoms on young apple fruit inoculated with ascospore isolates of $S$. pomi obtained from sugar maple, white oak, blackberry, sassafras, and black willow. Hickey (32) also found that apples inoculated with isolates from blackberry developed typical flyspeck symptoms. Z. jamaicensis and $S$. pomi were observed on young apple fruit inoculated with ascospore isolates of $S$. pomi from apple and wild hosts $(4,22)$, and on young apple fruit exposed to mature thyriothecia on a stem of Rubus parviflorus (4). In addition, S. pomi and Z. jamaicensis were observed on apple, carnation, banana, honeysuckle, and Rubus spp. inoculated with conidia of $Z$. jamaicensis from carnation $(4,22)$. Isolates of $Z$. jamaicensis from grapevine, Japanese persimmon, and apple were virulent on all three of these same fruit (53).

Disease development and epidemiology. The fungus overwinters as thyriothecia on infected reservoir hosts (see above), apple twigs (89), and discarded cull apple fruit in the orchard (20). Development of thyriothecia occurs in two stages: there is a period in which the thyriothecial stroma matures to a point where ascogenous hyphae are produced, and a period in which the asci mature (46). Environmental and/or biochemical factors may affect the progression of these stages. An increasing percentage of thyriothecia on Rubus canes in Massachusetts produced mature ascospores, when placed under favorable conditions, as winter and spring progressed. However, about $58 \%$ of thyriothecia did not produce asci in early April when placed under favorable conditions. This implies that an initial phase of development of the thyriothecium is needed before asci can develop.

Ascospores mature and are discharged in the spring during a single discrete period (46) and initiate primary infections on apples and reservoir hosts (4). The time of ascospore maturity varies from season to season and among geographical locations $(2,20,46)$. In Massachusetts, the peak of ascospore maturity at one site was in late May, but 1 year later at the same site, the peak occurred in June (46). First fruit infections occurred by late May or early June in North Carolina (9), near the end of June in West Virginia (34), and between the end of April and the beginning of May in Alabama (45).

Once apples are infected in the field, it takes about 1 month for symptoms to develop (89); however, symptoms may become visible within 10 to 12 days under optimal conditions $(88,89)$. First symptoms of flyspeck have been observed in midMay (88) and from June to mid-July in North Carolina (9), in mid-June in Alabama (45), and from late July to late August in Massachusetts (46).

Conidia are produced on infected plants and apple fruit and cause secondary infec- 
tions throughout the growing season $(32,46,88,89)$. Sutton (88) reported that conidia were trapped in apple orchards and near reservoir hosts in North Carolina from late May or early June through mid-September (harvest). The number of colonies per fruit and percent affected fruit increased until mid-September.

The majority of conidia in apple orchards and near reservoir hosts in North Carolina were trapped between 7:00 A.M. and 1:30 P.M. (88). During this time, flyspeck colonies wet with dew, fog, or rain, dry, resulting in conditions favorable for conidia to be dispersed $(46,51,89)$. Hourly spore concentrations were positively correlated with temperature and wind speed and negatively correlated with relative humidity and leaf wetness. There was no significant correlation with rainfall (88).

Ecology. Observations in the field indicate that warm and moist or humid conditions are needed for disease development $(10,20,21,46,76)$. Brown and Sutton (10) reported that first symptoms of flyspeck and sooty blotch in North Carolina could be predicted based on the number of hours of leaf wetness of $4 \mathrm{~h}$ duration or greater accumulated from the first rain that occurred 10 days after petal fall, and Sharp and Yoder (76) observed that more than
$100 \mathrm{~h}$ of relative humidity $\geq 95 \%$ was required for symptom development.

The optimum temperature for mycelial growth of $Z$. jamaicensis in vitro has been reported to be from 15 to $24^{\circ} \mathrm{C}$ (2), 20 to $25^{\circ} \mathrm{C}$ (53), and 16 to $24^{\circ} \mathrm{C}$ (58), although growth occurs over a wide range of temperatures (5 to $27^{\circ} \mathrm{C}$, [2]; 6 to $28^{\circ} \mathrm{C}$, [53]; 12 to $28^{\circ} \mathrm{C}$, [58]). Ocamb-Basu and Sutton (58) found that relative humidity $\geq 96.2 \%$ was needed for growth. Conidial production occurred from 12 to $24^{\circ} \mathrm{C}$ and was greatest from 16 to $20^{\circ} \mathrm{C}$. Relative humidity $\geq 96.2 \%$ was needed for conidial production. Conidia germinated from 8 to $28^{\circ} \mathrm{C}$ and required relative humidity $\geq 96.2 \%$ to germinate. Germination of conidia and development of germ tubes were greatest at 20 and $28^{\circ} \mathrm{C}$ at $99.7 \%$ relative humidity. Ascospores germinated from 16 to $28^{\circ} \mathrm{C}$ and required relative humidity $>96.2 \%$.

Development of ascospores within thyriothecia is also affected by temperature and relative humidity. Development of asci on Rubus canes was initiated at 4 and $6^{\circ} \mathrm{C}$ at high humidity and at $7^{\circ} \mathrm{C}$ at low to high humidity, but mature spores were produced only at $9,10,14$, and $21^{\circ} \mathrm{C}$ at high humidity $(46,47)$. In the orchard, there was a linear relationship between total mature ascospores and accumulated temperature (46).

\section{Control}

Control of sooty blotch and flyspeck is based on a combination of cultural practices and chemical control.

Cultural practices. The importance of cultural practices in managing sooty blotch and flyspeck has been known for many years. Most of these practices are associated with selecting or creating an environment less favorable for disease development. The importance of a good drying site was recognized at the turn of the twentieth century by Selby (74) and Sheldon (77), who recommended selecting a site "where the trees will receive plenty of air and sunshine."

Similarly, the importance of pruning to open the canopy and facilitate drying was prominent among recommendations for managing the diseases in the early plant pathological literature $(7,11)$. Colby (11), writing in 1920, stated that "opening the trees to sunshine and air should be the first measure taken to combat the trouble." Hickey (33) noted that pruning created an environment less favorable for the diseases, and also reduced the inoculum and improved fungicide coverage. Latham and
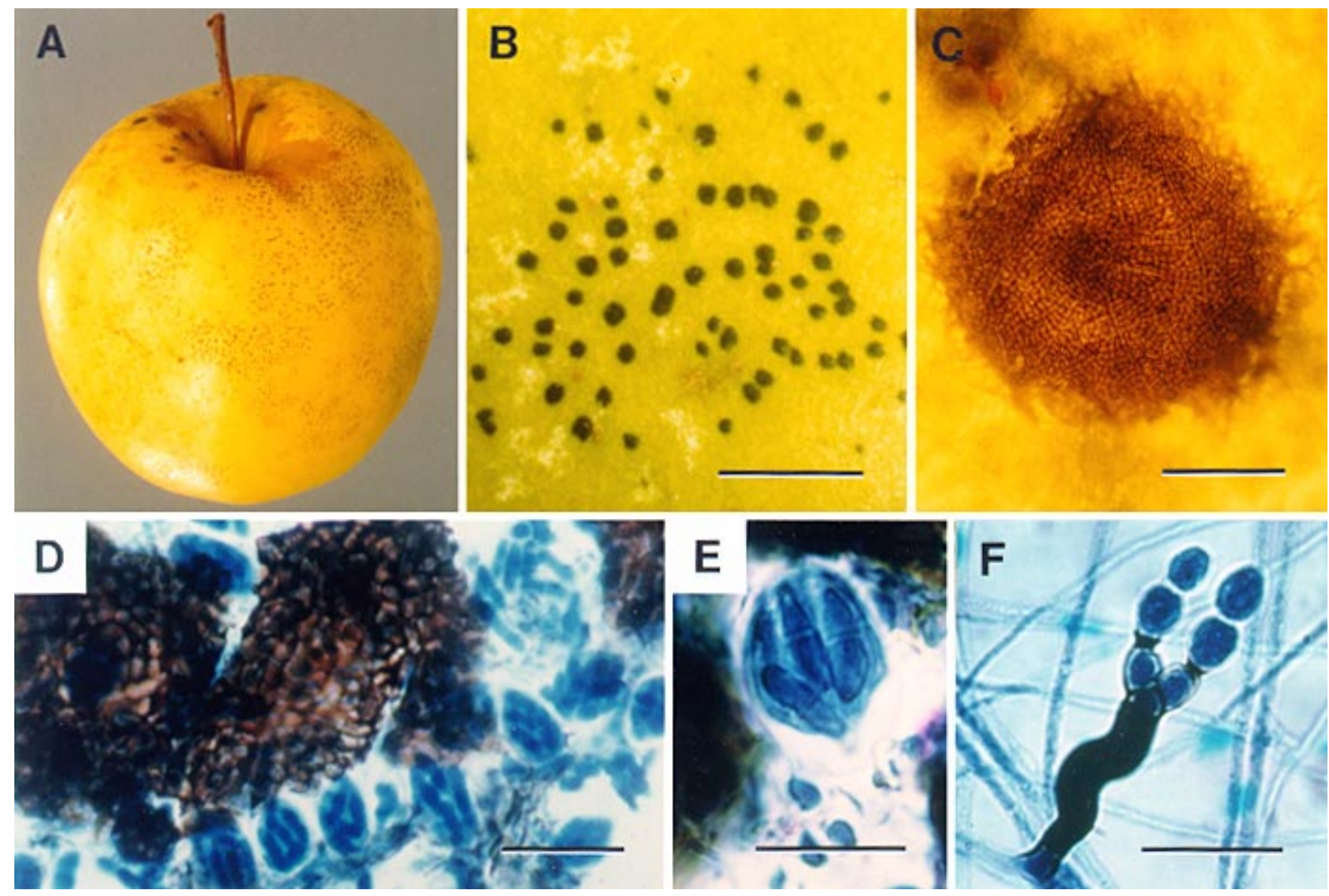

Fig. 5. (A) Schizothyrium pomi, associated with flyspeck, on apple. (B, C) Immature thyriothecia of S. pomi on apple. When mature, the thyriothecium cracks in the light colored circular area seen in (C). Bar = $2 \mathrm{~mm}$ in (B) and $100 \mu \mathrm{m}$ in (C). (D, E) Ascospores and asci released from a crushed thyriothecium obtained from blackberry stem. Bar $=30 \mu \mathrm{m}$ in (D) and $15 \mu \mathrm{m}$ in (E). (F) Conidiophore and conidia of Zygophiala jamaicensis grown on agar medium. Bar $=20 \mu \mathrm{m}$. 
Hollingsworth (45), Ocamb-Basu et al. (59), and Cooley et al. (12) conducted studies that provided more quantitative data to support the value of pruning. Latham and Hollingsworth (45) showed that the incidence of sooty blotch and flyspeck could be reduced by an average of almost $30 \%$ by "severe pruning." Ocamb-Basu et al. (59) demonstrated that dormant pruning in a nonsprayed orchard significantly reduced the incidence and severity of sooty blotch in 2 of 3 years, but there was no consistent effect on the incidence and severity of flyspeck. They monitored temperature and relative humidity within the canopies of pruned and nonpruned trees, but no differences could be detected between them. Cooley et al. (12) found that summer pruning (early July) reduced the incidence of flyspeck by approximately $50 \%$ during a 2-year study in which fungicides were not applied. Summer pruning also resulted in a significant reduction in disease and reduced the number of fruit downgraded from US Fancy Grade in a similar study conducted in commercial orchards. Summer pruning decreased the number of hours of relative humidity $>95 \%$, increased the evaporative potential, and resulted in increased spray deposits in the upper two-thirds of the tree canopy. There were no significant differences in temperature or hours of leaf wetness between trees that were and were not summer pruned.

The fungi that cause sooty blotch and flyspeck grow on numerous reservoir hosts $(2-4,11,20,22,23,32,39,53,56,57,89,90,95)$. The importance of these hosts was recognized by Hickey (32), who indicated that the removal of susceptible plants near the orchard would aid in reducing the inoculum. Sutton (88) located Burkard spore traps between apple orchards and patches of blackberry (Rubus argutus Link) and was able to trap large numbers of airborne conidia of Z. jamaicensis from late May until harvest. He noted that Rubus spp. are among the most widespread hosts near orchards in North Carolina and recommended mowing them in ditchbanks near orchards or along orchard borders to reduce inoculum levels.

Host resistance. There is some variation among cultivars in their susceptibility to sooty blotch and flyspeck. Differences have been related to skin color and maturity date $(3,11,31)$. Symptoms are more visible on light-skinned cultivars, and the diseases tend to be more severe on those cultivars that mature later in the growing season.

Belding (6) noted that the severity of sooty blotch and flyspeck varied among cultivars or selections harvested on the same date during the 1989 to 1992 growing seasons. He reasoned that, since the fungi involved in the sooty blotch complex grow epiphytically on the cuticle, any difference among cultivars might be due to differences in one or more of the components of the epicuticular wax. Differences were found among cultivars in the five principal components of the epicuticular wax, but none of the five components supported in vitro growth of $P$. fructicola or $L$. elatius unless amended with dilute apple juice. He concluded that $P$. fructicola and L. elatius obtain their nutrients primarily from fruit leachates. Thus, any differences in disease severity among cultivars may be related to the permeability of the cuticle to these leachates.

Biological control. Little progress has been made in the biological control of sooty blotch and flyspeck. Chaetomium globosum and Trichoderma harzianum have been investigated for their abilities to control the diseases. Davis et al. (13) reported that a hydrolyzed, colloidal, cellulose-based formulation of C. globosum (NRRL 6296), applied with an oil-based sticker, reduced the number of flyspeck colonies by $63 \%$ compared with an untreated control, and controlled sooty blotch as effectively as the fungicide standard. Kiyomoto (42) found that $T$. harzianum strain T-22, applied either every 7 or 14 days from mid-August until harvest, did not significantly reduce incidence of sooty blotch and flyspeck compared with the nonsprayed control. Ploper and Backman (61) investigated the effects of foliar applications of colloidal suspensions of various biopolymers and found that both sooty blotch and flyspeck were reduced. None of these biological controls has been developed commercially for the control of sooty blotch and flyspeck.

Chemical control. The chemical control of sooty blotch and flyspeck over the past 110 years has gone through at least four phases: control with inorganic fungicides, especially Bordeaux mixture and lime sulfur; the transition from inorganic to organic fungicides; a resurgence of the diseases as a result of widespread use of concentrate pesticide applications and loss of or restrictions on use of various products; and improved control through use of eradicant spray programs based on models to time fungicide applications.

Control with inorganic fungicides. The first report of a fungicide trial for sooty blotch and flyspeck was by H. H. Lamson (43) in 1894 who, using Bordeaux mixture, reported that "spraying appears to be very effective against this trouble." Several years later, Lamson (44) showed that with use of a 5-5-50 Bordeaux mixture, the incidence of disease could be reduced from 77 to $18 \%$. Bordeaux mixture, applied every 2 to 4 weeks during the season, was generally recommended during the first decade of the twentieth century to control the diseases $(31,61,85)$. Most authors noted that fungicides applied to control more serious diseases (e.g., bitter rot) satisfactorily controlled sooty blotch and flyspeck $(31,62)$. By 1910, Bordeaux mixture was being replaced by lime sulfur, which was less phytotoxic (32). From this time until the late 1940s and early 1950s, Bordeaux mixture and lime sulfur were the principle fungicides used for the control of sooty blotch and flyspeck.

Control with organic fungicides. With the introduction of the monoalkyldithiocarbamate fungicide ferbam and the pthalamide fungicide captan, sooty blotch and flyspeck became a greater problem in many orchards. A. B. Groves wrote in the 1953 USDA Yearbook of Agriculture: Plant Diseases (26) that "the diseases have tended to reappear, however, in well-caredfor orchards since the widespread shift from inorganic insecticides and fungicides to the organic pesticides." Groves attributed the increase in the diseases in part to less persistence of organic fungicides and the use of fewer late-season sprays due to a reduction in insect problems with the use of DDT and other organic insecticides. In addition to these reasons, Hickey (32) suggested that the increase in the diseases was due to greater specificity of the organic fungicides and the tendency for growers to apply combined insecticidefungicide sprays as opposed to using a predetermined fungicidal spray program.

As research was conducted on the new organic fungicides, their advantages and weaknesses became more apparent. Hickey (32) noted that ferbam was superior to Bordeaux mixture on sooty blotch, but not on flyspeck. He found that captan was very active against $G$. pomigena in in vitro tests and attributed its failure to control sooty blotch in the orchard to its short residual activity. Swartwout et al. (91), Weaver (94), and Hickey (32) reported that the residual activity of captan was increased when it was combined with the insecticide lead arsenate. Hickey (32) suggested that this combination, which provided as much as 25 days longer control than captan alone, was effective because of the persistence of lead arsenate. These and other studies $(48,49)$ led to the development of a spray program similar to the one used today in which the cover sprays are applied every 10 to 14 days during the summer.

In the late 1950s and 1960s, the ethylene bisdithiocarbamate (EBDC) fungicides were introduced and incorporated in apple spray programs. These fungicides had greater residual activity than captan or the monoalkyldithiocarbamate fungicides. Hickey (33) found that zineb provided up to 60 days residual activity and suggested combinations of captan plus zineb for sooty blotch and flyspeck control for the mid-Atlantic growing region. Brown and Sutton (8) found that the residual control provided by mancozeb was 20 to 30 days longer for sooty blotch and 30 to 50 days longer for flyspeck than captan. Because of their excellent residual activity and broad spectrum of activity, the EBDC fungicides became widely used from the mid-1960s through the early 1990s. 
Resurgence of sooty blotch and flyspeck. The period from 1970 through the mid1990 s was characterized by two periods in which sooty blotch and flyspeck became more prevalent in many orchards. Both periods were associated, at least in part, with regulatory decisions that resulted in the loss of chemicals or restrictions on their use. The first period occurred in the early to mid-1970s. Some of the increase in disease at this time was associated with the loss of lead arsenate, which was used as an insecticide until the early 1970s and improved sooty blotch and flyspeck control, especially when captan was used $(32,86,94)$. Another factor that led to the resurgence of the diseases was the widespread use of concentrate spraying. By the early 1970 s, concentrate spraying was widely adopted by apple growers because pesticides could be applied more quickly and economically (49). Brown and Sutton (8) compared the control of sooty blotch and flyspeck with captan, mancozeb, and mancozeb plus dinocap (trade name, Dikar) when they were applied $1 \times$ (dilute), $5 \times$ (1983), or 6× (1984). Results indicated that disease control with captan was significantly less when captan or mancozeb was applied at $5 x$ or $6 x$ concentration (Table 1). Mancozeb plus dinocap did not control the disease well when applied at either $1 \times$ or $5 \times$ in 1983 , but in 1984 , control was significantly better when mancozeb plus dinocap was applied at $1 \times$ as opposed to $6 \times$. The authors observed more disease on the insides of tightly clustered fruit and suggested that fungicide coverage within clusters and on the back side of fruit was greater with dilute as opposed to concentrate spray applications. As a result of their study, the use of more dilute fungicide applications was recommended in areas where the diseases are a problem.

Thus in the 1980s, sooty blotch and flyspeck were controlled satisfactorily by most growers. The EBDC fungicides were used widely, and many growers (at least in the Southeast) had increased the water volume per hectare. Also in the 1980s, the benzimidazole fungicides, benomyl and thiophanate-methyl, were beginning to be inserted into the cover spray program, often in combination with captan, to improve sooty blotch and flyspeck control. However, in 1992, the United States Environmental Protection Agency placed new restrictions on the use of EBDC fungicides that did not allow any applications within 77 days of harvest and reduced the permitted rate per hectare from 8.96 to 3.36 $\mathrm{kg}$ a.i. in post-petal fall applications. As a result, sooty blotch and flyspeck became a more significant problem in the early 1990s. This resulted in a greater use of benzimidazole fungicides, usually in combination with ziram or captan, as well as more frequent fungicide applications at a time when there was increased pressure to reduce pesticide residues on fruit and in the environment.

Eradicant spray programs. The eradicant properties of the benzimidazole fungicides against the sooty blotch and flyspeck fungi have been known since the late 1970s. According to Hickey (33), applications of benomyl plus zineb or benomyl plus fenarimol, applied when sooty blotch and flyspeck were "uniformly established on a high percentage of the fruit," suppressed subsequent symptom development. Rosenberger et al. (69) found that a single application of benomyl plus metiram in mid-July eradicated infections established prior to fungicide application. Applications of benomyl made when flyspeck symptoms were just becoming visible arrested subsequent symptom development but were not as effective on sooty blotch. Brown and Sutton (9) conducted a series of experiments whereby the first fungicide applications after petal fall were made once first symptoms of sooty blotch were detected (approximately 1\% fruit affected). Captan and mancozeb did not demonstrate any eradicant activity but arrested symptom development. Combinations of captan or mancozeb with benomyl arrested symptom development and resulted in a decrease in sooty blotch symptoms at harvest compared with the nonsprayed control, but they were not as effective as a standard protectant program that included benomyl. The authors concluded that an eradicant pro- gram that begins with the onset of symptoms may be useful for processing fruit, but fruit quality is not satisfactory for the fresh market.

The best way to take advantage of the eradicant properties of the benzimidazole fungicides is in conjunction with a model to better time the application of the fungicides. Brown and Sutton (10) observed that symptoms of sooty blotch and flyspeck appeared in the orchard from early June until mid-July and reasoned that if they could predict the onset of symptoms, then the eradicant properties of the benzimidazole fungicides could be utilized more effectively. Typically, a benzimidazole fungicide is added to the summer spray program in the southeastern United States around first or second cover (mid- to late May, or about 3 to 4 weeks after petal fall). Brown and Sutton (10) monitored hours of leaf wetting, using a Dr. M. DeWit leaf wetness recorder, rainfall, and temperature during the 1987 to 1994 growing seasons and noted that first symptoms of sooty blotch and flyspeck appeared after an average of $273 \mathrm{~h}$ of leaf wetting of $4 \mathrm{~h}$ duration or greater had accumulated, beginning with the first rain that occurred 10 days after petal fall (Fig. 6). When benzimidazole applications were included in the spray program at 209 and $270 \mathrm{~h}$ of leaf wetting, using the criteria above, the control of sooty blotch and flyspeck was similar to that of the standard protectant treatment. They indicated that if the model had been used in North Carolina from 1987 to 1994, the average grower would have saved two benzimidazole sprays each year. They recommended that a threshold of 200 or $225 \mathrm{~h}$ of accumulated wetting should be used to time benzimidazole applications, but they suggested that under low inoculum situations, a higher threshold could be used.

The model has subsequently been modified by several researchers. Smigell and Hartman $(78,81)$ and Hartman $(27,28)$, in a series of studies over 5 years, used an electronic leaf wetness sensor and found that first symptoms were observed when 185 to $251 \mathrm{~h}$ of leaf wetting were accumu-

Table 1. Incidence and severity of sooty blotch and flyspeck on Golden Delicious apples sprayed with captan, mancozeb, or mancozeb combined with dinocap in dilute (1×) and concentrate (5x) applications in 1983 at the Mountain Horticultural Crops Research Station (adapted from Brown and Sutton [8] Tables 1 and 2)

\begin{tabular}{|c|c|c|c|c|c|c|c|c|}
\hline \multirow[b]{3}{*}{ Treatment $^{\mathrm{a}, \mathrm{b}}$} & \multicolumn{4}{|c|}{ Sooty blotch } & \multicolumn{4}{|c|}{ Flyspeck } \\
\hline & \multicolumn{2}{|c|}{ Fruit affected (\%) } & \multicolumn{2}{|c|}{ Severity ${ }^{\mathrm{c}}$} & \multicolumn{2}{|c|}{ Fruit affected (\%) } & \multicolumn{2}{|c|}{ Severity $^{c}$} \\
\hline & $1 \times$ & $5 x$ & $1 x$ & $5 x$ & $1 \times$ & $5 x$ & $1 \times$ & $5 x$ \\
\hline Captan 50WP & 53.3 & $96.7 * * \mathrm{~d}$ & 1.5 & $4.7 * * \mathrm{~d}$ & 70.0 & $89.7 * \mathrm{~d}$ & 2.6 & $6.9 * * \mathrm{~d}$ \\
\hline Mancozeb 80WP & 15.0 & $88.3 * *$ & 2.4 & 6.7 & 3.3 & 3.3 & 0.3 & 1.0 \\
\hline $\begin{array}{l}\text { Mancozeb combined } \\
\text { with dinocap 76.7WP }\end{array}$ & 68.3 & 76.7 & 1.9 & 2.3 & 3.3 & 3.3 & 0.7 & 0.4 \\
\hline
\end{tabular}

${ }^{a}$ Dilute rates for captan, mancozeb, and mancozeb combined with dinocap were $7.40 \mathrm{~kg} / \mathrm{ha}$.

${ }^{\mathrm{b}}$ Last spray was on 4 August; harvest was on 20 September.

c Severity for sooty blotch is percent surface covered; severity for flyspeck is number of colonies on affected fruit.

${ }^{d}$ Significantly different from dilute application according to $t$ test; * $P=0.05 ; * * P=0.01$. 
lated, beginning 10 days after petal fall. Subsequently, they have suggested $175 \mathrm{~h}$ of total wetting as a threshold for the insertion of a benzimidazole fungicide in the spray program. By using the program, up to four benzimidazole sprays a year have been saved in Kentucky. Gleason et al. (24), using the same model, compared the accumulation of leaf wetting on-site with an electronic sensor with predicted leaf wetness data obtained from a commercial forecasting firm (Skybit, Boalsburg, PA). Using the on-site data, they were able to use two less benzimidazole sprays than were used in the protectant program and one less when using leaf wetness data from the commercial company.

Hartman (29) and Smigell and Hartman $(79,80,82)$ used their version of the sooty blotch-flyspeck model to time the placement of multilayer fruit bags on developing fruit. Multilayer fruit bags are used to modify fruit color for specialty markets. This novel approach has the potential to significantly reduce pesticide use. Over 3 years, they found that bags provided acceptable disease control when applied before $175 \mathrm{~h}$ of wetting accumulated. It was concluded that bags needed to be in place in early July to provide acceptable disease control (80).

A somewhat similar approach was utilized for timing benzimidazole sprays to control flyspeck in New York (1,64-68). The authors reasoned that the last fungicide spray applied to control scab, which typically includes benomyl, thiophanatemethyl, captan, or ziram, provided 14 to 21 days residual activity against flyspeck, depending on the particular fungicide. After the 14- to 21-day period, total hours of leaf wetting are accumulated until $100 \mathrm{~h}$ is reached. This $100-\mathrm{h}$ period is referred to as a "protection gap" and is based on the

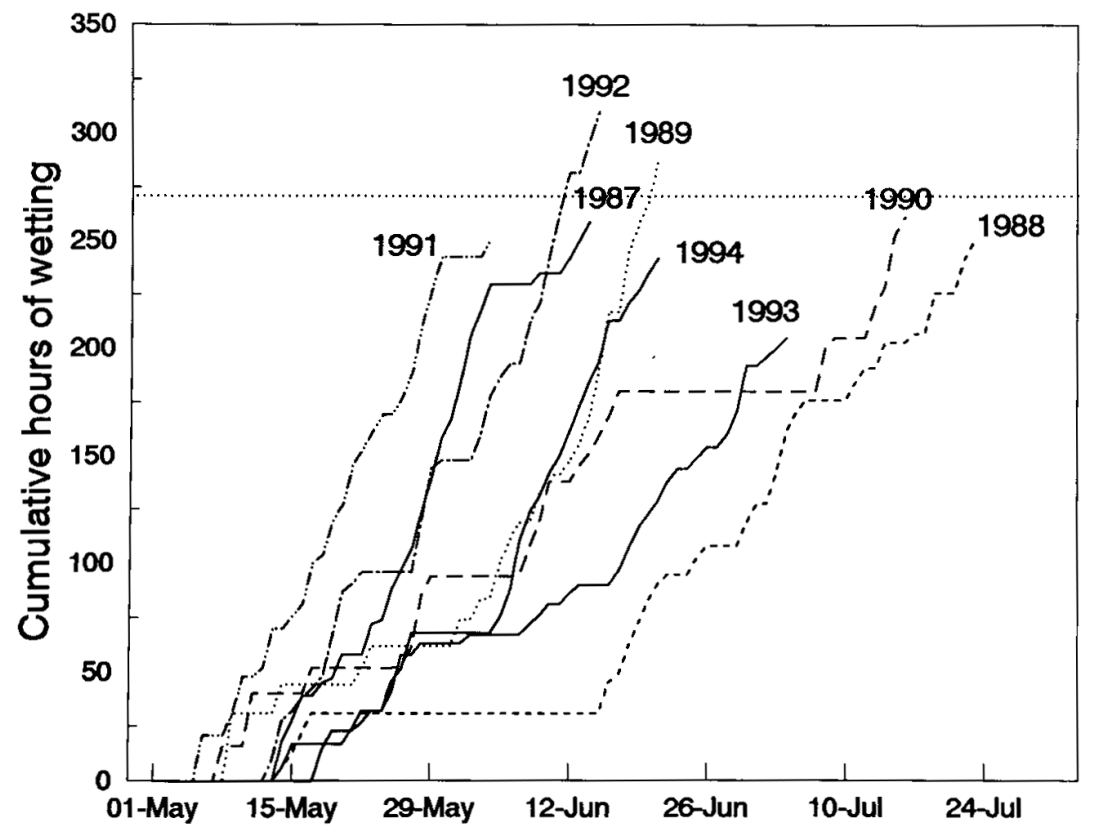

Fig. 6. Cumulative hours of wetting of $4 \mathrm{~h}$ duration or greater beginning with the first rain that occurred 10 days after petal fall until first symptoms of sooty blotch and flyspeck were observed at the Mountain Horticultural Crops Research Station, Fletcher, NC, from 1987 to 1994 . Horizontal line is mean for the 8-year period (273 h). After Brown and Sutton (10). Copyright 1995, The American Phytopathological Society.

Table 2. Relative activity of fungicides or fungicide groups on sooty blotch and flyspeck

\begin{tabular}{lcc}
\hline & \multicolumn{2}{c}{ Relative activity } \\
\cline { 2 - 3 } Fungicide and rate (a.i.)/ha & Sooty blotch & Flyspeck \\
\hline Captan $3.36 \mathrm{~kg}$ & $++++^{\mathrm{a}}$ & +++ \\
EBDC $($ maneb, mancozeb, metiram) $5.38 \mathrm{~kg}$ & ++++++ & ++++++ \\
EBDC $2.68 \mathrm{~kg}$ & +++ & ++++ \\
Dithiocarbamates (ziram, thiram, ferbam) $5.15 \mathrm{~kg}$ & ++++ & +++++ \\
EBIc (fenarimol, myclobutanil, triflumizole) $0.14-0.28 \mathrm{~kg}$ & + & ++ \\
Benzimidazole (benomyl, thiophanate-methyl) $0.28-0.85 \mathrm{~kg}$ & ++++ & +++++ \\
Strobilurin (kresoxim-methyl, trifloxystrobin) $0.07-0.22 \mathrm{~kg}$ & +++++ & ++++++ \\
\hline a Number of pluses reflects relative activity of fungicide or & group of fungicides. + = little \\
activity, ++++++ = high activity. & & \\
b Ethylene bisdithiocarbamate fungicides. & & \\
${ }^{c}$ Ergosterol biosynthesis inhibiting fungicides. &
\end{tabular}

ability of benzimidazole fungicides to eradicate existing infections during this time period. This approach has worked very well in studies conducted in New York over the past 5 years.

Currently used fungicides. The activities of some of the fungicides currently used to control sooty blotch and flyspeck are listed in Table 2. The activity listed for each fungicide or group of fungicides is based on its use every 14 days during the summer growing period. Rates listed are in the middle to upper range labeled for use by the EPA. If allowed by the label, the activities of most fungicides can be improved by using rates higher than those listed. Many of the fungicides listed are used in combination with one another to enhance their activity or increase their spectrum of activity against other diseases in the apple summer disease complex. For example, captan and ziram are usually used in combination with a benzimidazole fungicide. There is no report of resistance of the fungi in the sooty blotch-flyspeck complex to these fungicides.

Most of the fungicides listed have some activity against both $Z$. jamaicensis and the fungi in the sooty blotch complex; however, there are some differences in their relative activity against the fungi causing the two diseases. For example, captan is more active against the sooty blotch fungi than Z. jamaicensis, whereas mancozeb and the benzimidazole fungicides are more active against $Z$. jamaicensis. L. elatius appears to be the most difficult member of the sooty blotch complex to control. Groves (26) observed, almost 50 years ago, that the fuliginous mycelial type was more common in orchards using the new organic fungicides. Sutton (86) and Johnson (35) found that the in vitro activity of most fungicides was less against $L$. elatius than $P$. fructicola. It is likely that, as new fungicides with site-specific activity are released and incorporated into the spray program, one or more members of the sooty blotch and flyspeck complex will become more important.

Postharvest control. Sooty blotch and flyspeck can develop in storage. The extent of disease development is usually related to the length of time between the last fungicide application and harvest (16-18). Drake (16-18) found that when symptomless fruit were stored for 6 months at 0 to $1{ }^{\circ} \mathrm{C}$, extensive sooty blotch and flyspeck developed when the last spray was made 8 to 10 weeks before harvest. However, few symptoms developed when fruit were sprayed within 4 to 6 weeks of harvest. Fungicide treatments that were most effective before harvest resulted in the least sooty blotch and flyspeck development in storage.

The eradicant activity of sodium hypochlorite, when used as a postharvest dip, has been known for at least 70 years. Colby (11) observed that "sooty blotch is 
easily removed by immersing apples for 3 to $6 \mathrm{~min}$ in Javelle water." (Javelle water [sodium hypochlorite] is made by boiling bicarbonate of soda in water for $15 \mathrm{~min}$ and stirring in chlorine of lime.) The use of a chlorine dip as an eradicant was popularized in the 1990s by Hendrix (30) for use in an IPM program. Most symptoms could be removed by dipping fruit for 5 to $7 \mathrm{~min}$ in a $500 \mathrm{ppm}$ solution of chlorine, followed by brushing and a fresh water rinse. By using the technique, he was able to reduce the incidence of sooty blotch from 100 to $0 \%$ and that of flyspeck from 100 to $27 \%$.

Conclusions. Sooty blotch and flyspeck are two of the most widely distributed apple diseases in the warm, moist growing areas of the world. As the etiology of sooty blotch is studied, it is probable that additional fungi will be associated with the disease. The implications of this are unknown, but differences in the sensitivities of these fungi to fungicides may result in variation in the ability to control the diseases in different areas of the world. Because the prospects for cultivar resistance and biological control are poor, at least in the immediate future, management of the diseases will continue to be based on cultural practices designed to create an environment less favorable to the diseases and reduce the inoculum levels, and fungicide sprays. In the future, we will likely see periods during which either or both diseases become more important as older broad-spectrum fungicides are no longer used and newer, site-specific fungicides are introduced.

\section{Acknowledgments}

We thank Robert Milholland and Charles Hodges for their valuable comments on the manuscript, Osama Anas and Marvin Williams for helping with the figures, and Paul Peterson and the Plant Pathology History Program at North Carolina State University for bringing the McMurtrie watercolors to our attention.

\section{Literature Cited}

1. Agnello, A., Kovach, J., Nyrop, J., Reissig, H., Rosenberger, D., and Wilcox, W. 1999. Timing sprays to control flyspeck. Pages 2223 in: Apple IPM: A guide for sampling and managing major apple pests in New York State. NY State IPM Program, Geneva, Publ. 207.

2. Baines, R. C. 1940. Pathogenicity and hosts of the fly-speck fungus of apple. (Abstr.) Phytopathology 30:2.

3. Baines, R. C., and Gardner, M. W. 1932. Pathogenicity and cultural characters of the apple sooty-blotch fungus. Phytopathology 22:937-952.

4. Baker, K. F., Davis, L. H., Durbin, R. D., and Snyder, W. C. 1977. Greasy blotch of carnation and flyspeck of apple: Diseases caused by Zygophiala jamaicensis. Phytopathology 67:580-588.

5. Beach, S. A. 1905. The Apples of New York. Vol. 1. J. B. Lyon Co., Albany, NY.

6. Belding, R. D. 1996. Epicuticular wax of apple and its relationship to sooty blotch incidence and captan retention. Ph.D. diss. North Carolina State University, Raleigh.

7. Brooks, C. 1912. Some apple diseases and their treatment. N.H. Agric. Exp. Stn. Bull. 157.

8. Brown, E. M., and Sutton, T. B. 1986. Control of sooty blotch and flyspeck of apple with captan, mancozeb, and mancozeb combined with dinocap in dilute and concentrate applications. Plant Dis. 70:281-284.

9. Brown, E. M., and Sutton, T. B. 1993. Time of infection of Gloeodes pomigena and Schizothyrium pomi on apple in North Carolina and potential control by an eradicant spray program. Plant Dis. 77:451-455.

10. Brown, E. M., and Sutton, T. B. 1995. An empirical model for predicting the first symptoms of sooty blotch and flyspeck of apples. Plant Dis. 79:1165-1168.

11. Colby, A. S. 1920. Sooty blotch of pomaceous fruits. Trans. Ill. Acad. Sci. 13:139-175.

12. Cooley, D. R., Gamble, J. W., and Autio, W. R. 1997. Summer pruning as a method for reducing flyspeck disease on apple fruit. Plant Dis. 81:1123-1126.

13. Davis, R. F., Backman, P. A., RodriguezKabana, R., and Kokalis-Burelle, N. 1991. Biological control of apple fruit diseases by Chaetomium globosum formulations containing a carbon source. (Abstr.) Phytopathology $81: 1152$

14. de Hoog, G. S. 1977. Rhinocladiella and allied genera. Pages 1-140 in: Studies in Mycology. No. 15. Centraalbureau voor Schimmelcultures, Baarn, the Netherlands.

15. Desmazières, M. J. B. H. J. 1849. Sur les plantes cryptogames récemment découvertes en France. Ann. Sci. Nat., sér. 3, Bot. 11:339365 .

16. Drake, C. R. 1970. Report No. 10. Fungic. Nematicide Tests 26:8-9.

17. Drake, C. R. 1972. Report No. 18. Fungic. Nematicide Tests 28:14.

18. Drake, C. R. 1974. Report No. 11. Fungic. Nematicide Tests 30:10.

19. Duggar, B. M. 1909. Sooty blotch and flyspeck of apple and other plants. Leptothyrium pomi (Mont. \& Fr.) Sacc. Pages 367-369 in: Fungous Diseases of Plants. Ginn \& Co., Boston.

20. Durbin, R. D., and Snyder, W. C. 1953. Ecology and hosts of flyspeck of apple in California. (Abstr.) Phytopathology 43:586.

21. Durbin, R. D., and Snyder, W. C. 1953. Flyspeck of apple in California. Plant Dis. Rep. $37: 166$

22. Durbin, R. D., Davis, L. H., Snyder, W. C., and Baker, K. F. 1953. The imperfect stage of Microthyriella rubi, cause of flyspeck of apple. (Abstr.) Phytopathology 43:470-471.

23. Gardner, M. W., and Baines, R. C. 1931. Cultural characters and host range of the apple sooty-blotch fungus. (Abstr.) Phytopathology 21:112.

24. Gleason, M. L., Zriba, N., and Domoto, P. A. 1999. Performance of Skybit data input to a disease-warning model for sooty blotch and flyspeck, 1998. Fungic. Nematicide Tests 54:6

25. Groves, A. B. 1933. A study of the sooty blotch disease of apples and the causal fungus Gloeodes pomigena. Va. Agric. Exp. Stn. Bull. 50:1-43.

26. Groves, A. B. 1953. Sooty blotch and flyspeck. Pages 663-666 in: Plant Diseases. U.S. Dep. Agric. Yearb. Agric.

27. Hartman, J. R. 1995. Evaluation of fungicide timing for sooty blotch and flyspeck control, 1994. Fungic. Nematicide Tests 50:11.

28. Hartman, J. R. 1996. Evaluation of fungicide timing for sooty blotch and flyspeck control, 1994. Fungic. Nematicide Tests 51:6.

29. Hartman, J. R. 1996. Evaluation of multilayer fruit bags for sooty blotch and flyspeck control, 1995. Biol. Cultural Tests 11:38.

30. Hendrix, F. F., Jr. 1991. Removal of sooty blotch and flyspeck from apple fruit with a chlorine dip. Plant Dis. 75:742-743.
31. Hesler, L. R., and Whetzel, H. H. 1917. Sooty-blotch and fly-speck. Pages 104-108 in: Manual of Fruit Diseases. MacMillan Company, New York.

32. Hickey, K. D. 1960. The sooty blotch and fly speck diseases of apple with emphasis on variation within Gloeodes pomigena (Schw.) Colby. Ph.D. diss. Pennsylvania State University, University Park.

33. Hickey, K. D. 1977. Sooty blotch and flyspeck suppression with two late-season fungicide sprays, 1976. Fungic. Nematicide Tests 34:8-9.

34. Hickey, K. D., Lewis, F. H., and Taylor, C. F. 1958. Time of apple fruit infection by Gloeodes pomigena and Mycrothyriella rubi. (Abstr.) Phytopathology 48:462.

35. Johnson, E. M. 1994. Etiology of apple sooty blotch disease and temperature and relative humidity effects on development of the fung in the associated complex. Ph.D. diss. North Carolina State University, Raleigh.

36. Johnson, E. M., and Sutton, T. B. 1994. First report of Geastrumia polystigmatis on apple and common blackberry in North America. Plant Dis. 78:1219.

37. Johnson, E. M., and Sutton, T. B. 2000. Response of two fungi in the apple sooty blotch complex to temperature and relative humidity. Phytopathology 90:362-367.

38. Johnson, E. M., Sutton, T. B., and Hodges, C. S. 1996. Peltaster fructicola: A new species in the complex of fungi causing apple sooty blotch disease. Mycologia 88:114-120.

39. Johnson, E. M., Sutton, T. B., and Hodges, C. S. 1997. Etiology of apple sooty blotch disease in North Carolina. Phytopathology $87: 88-95$

40. Kendrick, B. 1992. The Fifth Kingdom, 2nd ed. Focus Texts, Newburyport, MA.

41. Kirby, R. S. 1954. Relation of rainfall to occurrence of apple scab and sooty blotch. (Abstr.) Phytopathology 44:495.

42. Kiyomoto, R. K. 1999. Effects of Tricho derma harzianum strain T-22 on control of sooty blotch and flyspeck of apple, 1997 1998. Biol. Cultural Tests 14:44.

43. Lamson, H. H. 1894. Some fungus diseases of plants and their treatment. N.H. Agric. Exp. Stn. Bull. 19.

44. Lamson, H. H. 1903. Sooty spot. Apple. Pear. Pages 60-61 and 65 in: Fungous diseases and spraying. N.H. Agric. Exp. Stn. Bull. 101

45. Latham, A. J., and Hollingsworth, M. H. 1973. Incidence and control of sooty blotch and flyspeck on apples in Alabama. Auburn Univ. Agric. Exp. Stn. Circ. 208.

46. Lerner, S. M. 1999. Studies on the biology and epidemiology of Schizothyrium pomi, causal agent of flyspeck disease of apple. M.S. thesis. University of Massachusetts, Amherst.

47. Lerner, S., and Cooley, D. R. 1995. Effects of temperature and relative humidity on maturation of ascospores of Schizothyrium pomi, flyspeck of apple. (Abstr.) Phytopathology 85:1557.

48. Lewis, F. H., and Hickey, K. D. 1958. Effective life of fungicides as a factor in the contro of sooty blotch and flyspeck of apple. (Abstr.) Phytopathology 48:462.

49. Lewis, F. H., and Hickey, K. D. 1972. Fungicide use on deciduous fruit trees. Annu. Rev. Phytopathol. 10:399-428.

50. Martyn, E. B. 1945. A note on banana lea speckle in Jamaica and some associated fungi. Commonw. Mycol. Inst. Mycol. Pap. 13:1-5.

51. Meredith, D. S. 1963. Violent spore release in some Fungi Imperfecti. Ann. Bot. 27:39-47.

52. Montagne, C. 1834. Notice sur les plantes cryptogames récemment découvertes en France. Ann. Sci. Nat., sér. 2, Bot. 1:295-349.

53. Nasu, H., Fujii, S., and Yokoyama, T. 1985. Zygophiala jamaicensis Mason, a causal fungus of flyspeck of grape, Japanese persimmon and apple. Ann. Phytopathol. Soc. Jpn. 
51:536-545.

54. Nasu, H., Hatamoto, M., and Kunoh, H. 1986. Behavior of causal fungus and process of lesion on flyspeck-affected berries of grape. Ann. Phytopathol. Soc. Jpn. 52:445-452.

55. Nasu, H., and Kunoh, H. 1986. A unique sclerotium-like structure produced by Zygophiala jamaicensis on grape berries. Trans. Mycol. Soc. Jpn. 27:225-233.

56. Nasu, H., and Kunoh, H. 1987. Distribution of Zygophiala jamaicensis in Okayama Prefecture, Japan. Trans. Mycol. Soc. Jpn. 28:209213.

57. Nasu, H., and Kunoh, H. 1987. Scanning electron microscopy of flyspeck of apple, pear, Japanese persimmon, plum, Chinese quince, and pawpaw. Plant Dis. 71:361-364.

58. Ocamb-Basu, C. M., and Sutton, T. B. 1988. Effects of temperature and relative humidity on germination, growth, and sporulation of Zygophiala jamaicensis. Phytopathology 78:100-103.

59. Ocamb-Basu, C. M., Sutton, T. B., and Nelson, L. A. 1988. The effects of pruning on incidence and severity of Zygophiala jamaicensis and Gloeodes pomigena infections of apple fruit. Phytopathology 78:1004-1008.

60. Pirozynski, K. A. 1971. Note on Geastrumia polystigmatis. Mycologia 63:897-901.

61. Ploper, L. D., and Backman, P. A. 1991. Modification of leaf microflora by foliar amendments and effects on diseases of tomato, potato, and apple. (Abstr.) Phytopathology 81:1152.

62. Quintance, A. L., and Scott, W. M. 1912. The more important insect and fungous enemies of the fruit and foliage of the apple. U.S. Dep. Agric. Farmers Bull. 492

63. Rosenberger, D. A., Engle, C. A., and Meyer, F. W. 1996. Effects of management practices and fungicides on sooty blotch and flyspeck diseases and productivity of Liberty apples. Plant Dis. 80:798-803.

64. Rosenberger, D. A., Engle-Ahler, C. A., and Meyer, F. W. 1999. Using Benlate and Topsin $\mathrm{M}$ as eradicants for flyspeck following a midsummer spray gap, 1998. Fungic. Nematicide Tests 54:17.

65. Rosenberger, D. A., Meyer, F. W., and Engle, C. A. 1996. Effects of fungicides and application timing on incidence of flyspeck on Liberty apples, 1995. Fungic. Nematicide Tests 51:19

66. Rosenberger, D. A., Meyer, F. W., and Engle, C. A. 1997. Controlling flyspeck with ziram, captan, Benlate, and sulfur used in various combinations, 1996. Fungic. Nematicide Tests $52: 26$

67. Rosenberger, D. A., Meyer, F. W., and Engle, C. A. 1997. Timing summer fungicide sprays for sooty blotch and flyspeck, 1996. Fungic. Nematicide Tests 52:23.

68. Rosenberger, D. A., Meyer, F. W., and Engle, C. A. 1998. Using Benlate and Topsin M as eradicants for flyspeck following a mid-summer spray gap, 1997. Fungic. Nematicide Tests 53:27.

69. Rosenberger, D. A., Meyer, F. W., and Rist, D. L. 1990. Effect of spray timing on incidence and severity of sooty blotch and flyspeck on Liberty apple, 1989. Fungic. Nematicide Tests 46:31

70. Saccardo, P. A. 1880. Fungi gallici lecti. Michelia 2:39-135.

71. Saccardo, P. A. 1883. Phyllachora pomigena (Schw.) Sacc. Syll. Fung. 2:622. Friedlander \& Sohn, Berlin.

72. Saccardo, P. A. 1884. Syll. Fung. 3:623. Friedlander \& Sohn, Berlin.

73. Schweinitz, L. D. 1832. Dothidea pomigena. Page 232 in: Transactions of the American Philosophical Society, New Series, Philadelphia, PA.

74. Selby, A. D. 1900. A Condensed Handbook of the Diseases of Cultivated Plants in Ohio. Ohio Agric. Exp. Stn. Bull. 121.

75. Selby, A. D. 1910. A Condensed Handbook of the Diseases of Cultivated Plants in Ohio. Ohio Agric. Exp. Stn. Bull. 214:307-456.

76. Sharp, W. L., and Yoder, K. S. 1985. Correlation between humidity periods and sooty blotch and flyspeck incidence in Virginia apple orchards. (Abstr.) Phytopathology 75:628.

77. Sheldon, J. L. 1905. A report on diseases of the state. W. Va. Univ. Agric. Exp. Stn. Bull. 96.

78. Smigell, C. G., and Hartman, J. R. 1997. Evaluation of fungicide timing for sooty blotch and flyspeck control, 1996. Fungic. Nematicide Tests 52:31.

79. Smigell, C. G., and Hartman, J. R. 1997. Evaluation of multi-layer fruit bags for sooty blotch and flyspeck control, Caldwell County, Kentucky, 1996. Biol. Cultural Tests 12:44.

80. Smigell, C. G., and Hartman, J. R. 1997. Evaluation of multi-layer fruit bags for sooty blotch and flyspeck control, Woodford County, Kentucky, 1996. Biol. Cultural Tests $12: 45$

81. Smigell, C. G., and Hartman, J. R. 1998. Evaluation of fungicide timing for sooty blotch and flyspeck control, 1997. Fungic. Nematicide Tests 53:31.

82. Smigell, C. G., and Hartman, J. R. 1998. Evaluation of multi-layer fruit bags for cork spot, sooty blotch and flyspeck control, 1997. Biol. Cultural Tests 13:44.

83. Sprague, C. J. 1856. Asteroma pomigena Proc. Boston Soc. Nat. History 5:339.

84. Sprague, C. J. 1856. Contributions to New England Mycology. Proc. Boston Soc. Nat. History 5:325-329.

85. Stevens, F. L., and Hall, J. G. 1910. Diseases of Economic Plants. MacMillan Company, New York.

86. Sutton, A. L. 1993. Distribution of mycelial types of Gloeodes pomigena on apples in North Carolina and the effect of captan on their incidence, severity, and distribution. M.S. thesis. North Carolina State University, Raleigh.

87. Sutton, A. L., and Sutton, T. B. 1994. The distribution of the mycelial types of Gloeodes pomigena on apples in North Carolina and their relationship to environmental conditions. Plant Dis. 78:668-673.

88. Sutton, T. B. 1990. Dispersal of conidia of Zygophiala jamaicensis in apple orchards. Plant Dis. 74:643-646.

89. Sutton, T. B. 1990. Sooty blotch and flyspeck. Pages 20-22 in: Compendium of Apple and Pear Diseases. A. L. Jones and H. S. Aldwinkle, eds. American Phytopathological Society, St. Paul, MN

90. Sutton, T. B., Bond, J. J., and Ocamb-Basu, C. M. 1988. Reservoir hosts of Schizothyrium pomi, cause of flyspeck of apple, in North Carolina. Plant Dis. 72:801

91. Swartwout, H. G., Jenkins, L., and Martin, W. R., Jr. 1952. Spray suggestions for commercial apple orchards. Missouri Ext. Circ. 611

92. Venkatasubbaiah, P., Sutton, T. B., and Chilton, W. S. 1995. The structure and biological properties of secondary metabolites produced by Peltaster fructicola, a fungus associated with apple sooty blotch disease. Plant Dis.79:1157-1160.

93. Von Arx, J. A. 1959. Ein Beitrag zur Kenntnis der Fliegenfleckenpilze. Proc. Koninkl. Nederl. Akad. Wetensch., ser. C. 62:333-340.

94. Weaver, L. O. 1953. Relation of fungicides to control of apple diseases on Stayman and Golden Delicious apples. Proc. CumberlandShenandoah Fruit Workers Conf. 29:26.

95. Zaring, D. 1929. Studies on sooty blotch of apples. M.S. thesis. Purdue University, West Lafayette, IN.

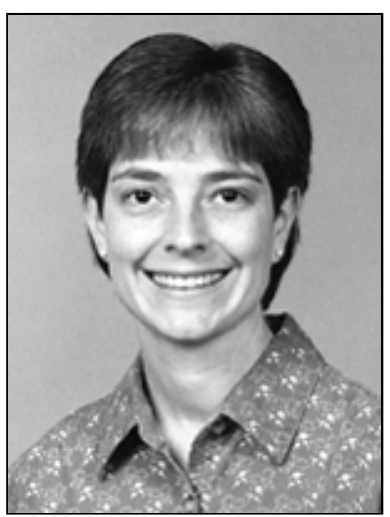

Sharon M. Williamson

Dr. Williamson is a postdoctoral research associate in the Department of Plant Pathology at North Carolina State University. She received a B.S. in biology from Albright College and M.S. and Ph.D. degrees in plant pathology from North Carolina State University. Currently, her research includes identification of fungi associated with apple sooty blotch and biocontrol of crown rot of banana.

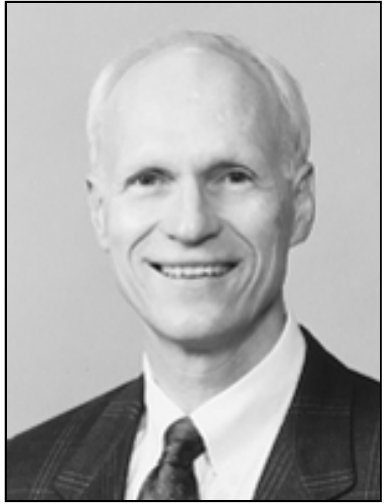

Turner B. Sutton

Dr. Sutton is a professor in the Department of Plant Pathology at North Carolina State University. He received his B.A. in botany and chemistry from the University of North Carolina at Chapel Hill and his M.S. and Ph.D. degrees from North Carolina State University. Following a post-doc at Michigan State University, he joined the faculty at NCSU in 1974. He has a joint appointment in research, extension, and teaching. His research and extension activities have focused on the epidemiology, biology, and management of summer diseases of apples. Through students from Costa Rica, he has worked on the epidemiology and control of black Sigatoka of banana and greasy spot of citrus and characterization of $\mathrm{Ra}$ dopholus similis on banana. Dr. Sutton has taught an undergraduate level course on fruit disease management and currently teaches a graduate level course on the epidemiology and management of plant diseases. 